\title{
Insinöörien edunvalvontaa
}

\author{
Anitra Komulainen
}

Sampsa Kaataja: Takamailta tekniikan kehityksen

kärkeen: Insinööriliitto yhteiskunnallisena vaikuttaja-

na 1919-2019, Insinööriliitto, Helsinki. 2019, 416 sivua,

ISBN 978-951-9055-99-2.

https://issuu.com/insinooriliitto/docs/ilry_2019_ta-

kamailta_tekniikan_kehityksen_karkeen

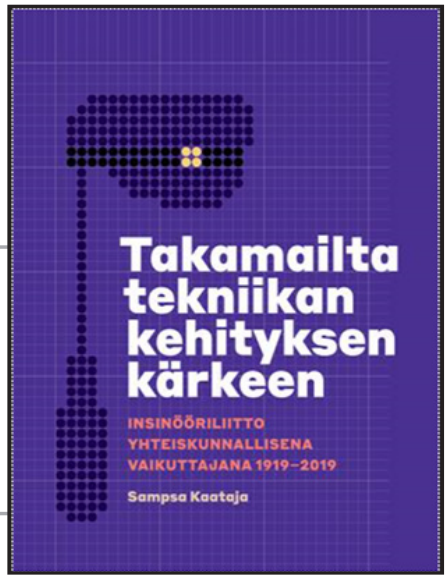

Sampsa Kaatajan tutkimus Takamailta tekniikan kehityksen kärkeen käsittelee Insinööriliiton vaiheita vuosina 1919-2019. Tuona aikana ammatillis-aatteellisesta yhdistyksestä kasvoi myös suurehko työmarkkinapoliittinen edunvalvontajärjestö. Muutos tapahtui 1970-luvulta alkaen, jolloin enää kolmannes liiton jäsenistä työskenteli johtotehtävissä ja valtaosa piti itseään "tavallisina työntekijöinä". Liiton suunnanmuutosta vauhditti työmarkkinajärjestöjen lisääntynyt yhteiskunnallinen valta. Monet insinöörit kokivat jäävänsä syrjään yleisestä palkka- ja työehtokehityksestä. Toki vastustustakin ilmeni, etenkin vanhemmassa polvessa, joka kavahti vasemmistolaisiksi luokittelemiaan painostustoimia.

Insinööriliitto oli verrattain pieni järjestö, joten se liittyi Akavaan. Yhdessä sen ja Korkeakouluinsinöörien ja Arkkitehtien Keskusliiton (KAL) kanssa syntyi Ylempien Toimihenkilöiden Neuvottelukunta (YTN), jossa järjestöt käsittelivät yhdessä insinöörien edunvalvontakysymyksiä. Yksi suurimmista työmarkkinapoliittisista voitoista oli työaikalainsäädännön ulottaminen myös insinööreihin vuodesta 1990 alkaen. Sitä ennen insinööreille ei maksettu ylitöistä palkkaa. Sen sijaan toinen sitkeästi ajettu tavoite, insinöörikunnan saaminen yleissitovien työehtosopimusten piiriin, ei toteutunut.

Liiton toinen tärkeä työsarka oli insinöörikoulutus. Tietynlainen suursaavutus oli insinöörien täydennyskoulutuskeskuksen, Inskon perustaminen yhdessä muiden insinöörijärjestöjen kanssa vuonna 1963. Insinööriliitto taisteli sitkeästi myös insinöörien liikakoulutusta vastaan ja korkeakoulutusstatuksen puolesta. 1990-luvun alussa syntyneet ammattikorkeakoulut antoivat vastauksen molempiin. Insinöörit tulivat korkeakoulutuksen piiriin, mutta koulutusmäärät kasvoivat liiton vastustuksesta huolimatta.

Kaataja tarkastelee Insinööriliiton muodonmuutoksia Suomen teknologisen ja yhteiskunnallisen kehityksen valossa, mutta selventävää kontekstia olisi voinut olla paikoitellen enemmänkin. On myös kummallista, että Kaataja mainitsee lähestymistavan olevan "poikkeuksellinen järjestöhistorioissa". Jo vuosikymmeniä historioitsijat ovat tilaustöissään käsitelleet aiheitaan asianmukaisten kontekstien avulla. Tämän pitäisi olla pikemminkin sääntö eikä poikkeus.

Kaatajan teoksen suurimpia ansioita ovat Insinööriliiton vivahteikkaan edunvalvontatyön käsittely, selkeät graafiset kaaviot ja muutamien insinöörien, kuten liiton perustajajäseniin kuuluneen ja maan ensimmäisen naisinsinöörin Sisko Anian sekä Elcoteqin perustajan Antti Piipon syvempi esittely. Muidenkin insinöörien, etenkin tärkeimpien vaikuttajien, taustoja olisi ollut syytä avata enemmän - toki mahdollisuuksien mukaan. Titteleiden ja tausto- 
jen puutteellisuus konkretisoituu etenkin silloin, kun Kaataja antaa ymmärtää, että henkilöt, eivät niinkään asiat, riitelivät erilaisissa edunvalvontakysymyksissä.

Insinööriliiton ammatillis-aatteellisen luonteen käsittely jää ohueksi. Insinöörihenki ei puhku tutkimuksesta. Missä ovat esimerkiksi insinöörien laulut, illanvietot, vitsit, kaskut ja tehdasvierailut, joiden avulla insinööriyttä määriteltiin? Pysyihän liitto 50 vuotta puhtaasti ammatillis-aatteellisena yhdistyksenä ilman edunvalvontatehtäviä. Tutkimuksesta löytyy kuitenkin pieniä tuulahduksia insinöörihengestä, vaikka Kaataja ei tee siitä johtopäätöksiä. Helmiä ovat mm. insinöörilakin seikkaperäiset käyttöohjeet sekä erään jäsenen kiukustunut kommentti, kun metsäteknikot muuttivat omin luvin tittelinsä metsäinsinööreiksi: "Ellette te pojat pidä varaanne, niin liittoonne on kohta tunkemassa kaikennäköiset karjatalousneuvojat ja keinosiementäjät.”

Insinööriyttä olisi voitu tarkastella mm. pohtimalla teknikkojen, insinöörien ja diplomiinsinöörien eriytymistä ja rajankäyntiä. Erityisesti kahden jälkimmäisen ammattikunnan erimielisyydet näkyvät läpi tutkimuksen, mutta eivät saa selityksiä. Myös eri alojen insinöörien käsittely jää ohueksi. Vaikuttiko esimerkiksi 2000-luvun jäsenkatoon myös insinöörien yhä vahvempi identifioituminen ammatti-alaansa yleisen insinööriyden sijasta? Insinöörihengen analysoimisessa olisivat voineet auttaa myös useammat haastattelut, Insinööriliiton alueyhdistyksistä kirjoitetut historiikit sekä laajempi tutustuminen tekniikan alan liitoista ja koulutuksesta tehtyihin tutkimuksiin.

Insinöörihengen puuttumisesta huolimatta Kaatajan tutkimus tuo arvokkaan lisän insinöörien, heidän professionalisaation ja etenkin edunvalvontatyön vähäiseen tutkimukseen. Toivottavasti teos kirvoittaa vielä monia ansiokkaita jatkotutkimuksia. Se on tärkeää "insinöörien maaksikin" kutsutun Suomen ja suomalaisten itseymmärryksen kannalta. Kaatajakin mainitsee, kuinka Suomi koulutti toiseksi eniten insinöörejä maailmassa heti EteläKorean jälkeen 2000-luvun alussa. 